\title{
Values in Students of Higher Education
}

\author{
Maria Helena de Agrela Gonçalves Jardim,2, Geraldo Bezerra da Silva Junior?, \\ Márcia Lúcia Sousa Dias Alves4
}

\author{
${ }^{1}$ The School of Health, University of Madeira, Funchal, Portugal \\ ${ }^{2}$ Psychology and Health Sciences, Public Health Graduate, Health Sciences Center, University of Fortaleza, Fortaleza, Brazil \\ ${ }^{3}$ Faculty of Medicine, Public Health Graduate Program, Health Sciences Center, University of Fortaleza, Fortaleza, Brazil \\ ${ }^{4}$ Abel Salazar Biomedical Sciences Institute, University of Porto, Porto, Portugal \\ Email: hjardim@uma.pt, geraldobezerrajr@unifor.br, marcialves96@hotmail.com
}

How to cite this paper: de Agrela Gonçalves Jardim, M. H., da Silva Junior, G. B., \& Alves, M. L. S. D. (2017). Values in Students of Higher Education. Creative Education, $8,1682-1693$.

https://doi.org/10.4236/ce.2017.810114

Received: July 19, 2017

Accepted: August 14, 2017

Published: August 17, 2017

Copyright $\odot 2017$ by authors and Scientific Research Publishing Inc. This work is licensed under the Creative Commons Attribution International License (CC BY 4.0).

http://creativecommons.org/licenses/by/4.0/

\begin{abstract}
The values of students occupy a central position in the cognitive system and on student's personality, because it includes components of knowledge, affective and behavioural, determining their attitudes and motivations. In order to respond to the question "what are the values in students of higher education" we have done a review of literature indexed in databases online, getting 23 articles published between 2008/2017. The reflection on the values of a student is of extreme importance to the educational system, due to the relationship between education and human values, resetting or recapturing the true role of the school in the formation of values. The results show that through the school it is possible to construct and develop human values in students, making it a place for this construction, without neglecting the importance of family. With the heterogeneity of methodologies of the studies, we suggest the development of more homogeneous research, materials and methods to evaluate the values of University students.
\end{abstract}

\section{Keywords}

Values, Students, University

\section{Introduction}

The values are guiding criteria of our choices, our inclinations and ultimately can materialize either in formation of our personality or in our decision-making. Therefore, we believe the values as judgments of truth, having a universal character. Being conveniently spiritual in nature and not sensitive, we take the concept of value as everything that is object of the evaluation and is seen as significant to someone.

When we decided to do something, we are conducting a choice, and we are 
certain preferences for some things over others, and we evoke certain reasons to justify our decisions. All these reasons can be supported by facts, but always implied certain values that justify or legitimize our preferences. The values are criteria according to which we prefer or not certain things, and are the reasons justifying or motivating our actions. The values are present in humans and their activities in the form of a duty of being and, on the other hand, assume that is independent and indifferent to the human world. In this sense, the value is one, universal and eternal, as opposed to the multitude, particularity and mutability of tangible results which should be the rule (Goergen, 2005).

A value is understood as a belief that belongs to desirable purposes or forms of behaviour that transcends the specific situations, which guide the selection or evaluation of behaviour, persons and events and that is organized by your relative importance to other values to form a system of priorities of values (Schwartz, 2006).

Identifying two main functions of the values, we can define as motivator (materialist or humanitarian law) and guidance (personal, social or central). The combination of such functions makes it possible to derive sub-functions that explain the psychosocial organization (structure) of human value. Such sub-functions are-Personal Values psychosocial: Experimental Values (emotion, stimulation, pleasure and sex), and values of realization (self-direction, success, power and prestige); Core values such as: Existence values (personal stability, health and survival) and Supra Individual Values (beauty, knowledge, social justice and maturity); Social values such as: Regulatory Values (obedience, social order, religion and tradition), and Interactional Values (affectivity, social support, and honesty) (Gouveia, 2008).

Based on these attributes the author has established a set of twenty-four basic values, terming them of basic human values-Survival; Sexual; Pleasure; Stimulation; Emotion; Personal Stability; Health; Religiosity; Social Support; Social Order; Affectivity; Coexistence; Success; Prestige; Power; Maturity; Auto direction; Privacy; Social Justice; Honesty; Tradition; Obedience; Knowledge and Beauty.

To mention that human values reflect the personality of the people and are the expression of the cultural, moral, affective, social and spiritual transmitted by the family, the school, social peer, by the institutions and the society in which they live, we must think of an education geared to meet the requirements imposed by these instances (Saviani, 2002).

The school is the first social space that is presented to the child after the family experience, and is basically the first scenario in which the child learns to be subject in life. To assume the role of social space, the University becomes one of the most important Institutions in the transmission of values, legitimized by society, coming soon after the family and the Church, privileged space of democratization and construction of citizenship (Marques, 2007). The school culture is not only the skill-set of determinants myths, behaviors, traditions, innovations and social relations, but also an ideological and scientific variable dependent on the 
general culture. In this way, the school can be pointed to as a crossing of cultures (Silva, 2006), that is, as a place of cultural intervention between the meanings, feelings and behaviours of the population and the development of future generations.

In a society in transformation, as this in the 21 st century, education in values is crucial to the formation of the subject future and their future. And, as what we see today is a profound crisis of values, educating in values arises as a permanent requirement, caused by the culture of modernity that presents an urgent need for an education geared toward the teaching of moral values. The global ecological calamity is adverse and incompatible between rich/poor, consumerism/ savings, fanaticism/atheism, apathy/agitation, unemployment/dubious occupations, placing the young university students in a dilemma, risking to destroy nature and be themselves victims of this degradation, expressing insecurity, anger, aggression, anxiety, depression and even some suicidal ideations and self-mutilation, calling into question to your own life.

\section{Methodological Design}

This research based on a systematic review of the literature with narrative summary. Was made exclusively in online databases, including EBSCOhost (Medline, Cochrane Central Register of Controlled Trials, Cochrane Database of Systematic Reviews, Psychology and Behavioural Sciences Collection, EJS E-Journals, British Nursing Index), SciELO and RCAAP (open access Scientific Repository of Portugal). As inclusion criteria we consider articles reported to the period between 2008 and 2017, in full-text, and about the values of University students. Were deleted articles that not reported the investigation around the theme under study.

The research resulted in 279 articles, being 110 articles on EBSCOhost, 8 on SciELO and 161 in RCAAP, by Key words: values, students, University. Some articles were common to databases and after a full reading of these were selected twenty-three studies for systematic review. The rest have been removed for not meeting the inclusion criteria (Figure 1).

For the analysis and synthesis of selected articles was conducted a summary table contemplating various information extracted from them and then a descriptive analysis of the results.

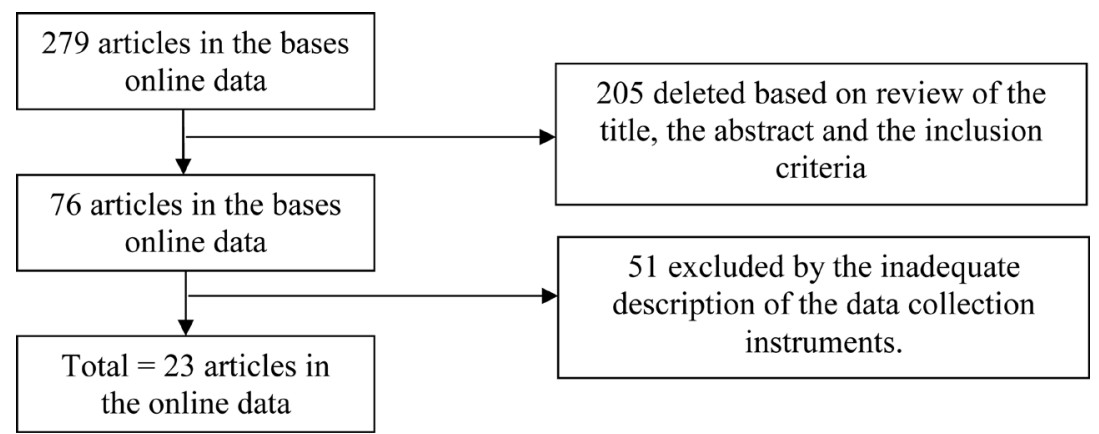

Figure 1. Design of reduction. 


\section{Results}

The synopsis of the articles and selected studies are described, in Table 1, according to the year of publication, study goals, type of study, methods, results and sample.

Table 1. General characterization of the articles reviewed.

\begin{tabular}{|c|c|c|c|c|c|}
\hline Author(s) & Date & Goal of the study & Type of study & Sample & Results \\
\hline $\begin{array}{l}\text { Park, Y. \& } \\
\text { Kim, B. }\end{array}$ & 2008 & $\begin{array}{l}\text { Relationship between } \\
\text { adherence to Asian and } \\
\text { European cultural values } \\
\text { and communication styles }\end{array}$ & Quantitative & 346 & $\begin{array}{l}\text {-Contentious, dramatic, accurate and open; } \\
\text {-Asians are more individualistic, little communicative and } \\
\text { interpersonal sensitivity in relation to European } \\
\text { Americans. }\end{array}$ \\
\hline Costa, $\mathrm{H}$. & 2008 & $\begin{array}{l}\text { Analyse the values of the } \\
\text { young Portuguese } \\
\text { consumers }\end{array}$ & Quantitative & 213 & $\begin{array}{l}\text {-The higher values are to be respected ( } 8.24) \text {, fun and } \\
\text { pleasure in life (8.17), self-respect ( } 8.11) \text {, sense of } \\
\text { accomplishment (7.95); Security ( } 7.83) \text {, and } \\
\text { self-actualization ( } 7.76) \text {; } \\
\text {-The lower rating, but still positive, were warm relations } \\
\text { with others (6.63), sense of belonging (6.21) and } \\
\text { excitement (5.96); } \\
\text {-Sense of accomplishment and self-respect }(\mathrm{r}=0.625 \text {, } \\
p<0.01) \text {; Self-respect and safety ( } \mathrm{r}=0.560, p<0.01) \text {; } \\
\text { Sense of accomplishment and self-actualization }(\mathrm{r}=0.546 \text {, } \\
p<0.01) \text {; Warm relations with others and excitement } \\
(\mathrm{r}=0.516, p<0.01) \text {; } \\
\text {-Men appreciate the excitement and the fun and pleasure } \\
\text { of life, related to fun, leisure and recreational activities; } \\
\text {-The female values self-actualizing linked to personal and } \\
\text { professional achievement. }\end{array}$ \\
\hline Novak, F. & 2008 & $\begin{array}{l}\text { Study how changes in the } \\
\text { traditional curriculum } \\
\text { structure can favour the } \\
\text { construction of desirable } \\
\text { values in society }\end{array}$ & Qualitative & 361 & $\begin{array}{l}\text {-privileges the construction of moral personalities because } \\
\text { it promotes the role, experience, discussion and } \\
\text { confrontation of social moral conflicts; } \\
\text {-Respect, dialogue, solidarity, equality and participation. }\end{array}$ \\
\hline $\begin{array}{l}\text { Almeida, L. \& } \\
\text { Tavares, P. }\end{array}$ & 2009 & $\begin{array}{l}\text { Characterize the value } \\
\text { system of a group of } \\
\text { University students and } \\
\text { relate the variables under } \\
\text { study }\end{array}$ & Quantitative & 271 & $\begin{array}{l}\text {-Humility (12.80) responsibility (11.65), Achievement } \\
\text { (11.64), concern for the environment (11.61), concern for } \\
\text { others (11.49), loyalty to family and Group (11.45); } \\
\text {-Relationship between the training area (courses of } \\
\text { humanity) and spirituality ( } p=0.03) \text {; } \\
\text {-In males is more valued responsibility (12.43), } \\
\text { independence (11.49), conducting (11.47) and concern for } \\
\text { the environment (11.42); } \\
\text {-In the female is more valued responsibility (13.03), } \\
\text { concern for others (11.84), Achievement (11.74), } \\
\text { independence (11.74) and concern for the environment } \\
\text { (11.73). }\end{array}$ \\
\hline Lins, $\mathrm{S}$. & 2010 & $\begin{array}{l}\text { Check which social values } \\
\text { that college students attach } \\
\text { to people } 1 \text { st and } 3 \text { rd world }\end{array}$ & Questionnaire & 220 & $\begin{array}{l}\text {-1st World countries were associated individual } \\
\text { development values and materialism; } \\
\text {-Third world countries were related values of social justice, } \\
\text { professional development, hedonism and religiosity. }\end{array}$ \\
\hline Cruz, E. & 2011 & $\begin{array}{l}\text { Identify values in young } \\
\text { Angolan University students }\end{array}$ & Quantitative & 756 & $\begin{array}{l}\text {-The most important thing is the family }(24.1 \%) \text {, religion } \\
(16.6 \%) \text { and dignity }(16 \%) \text {; } \\
-86.5 \% \text { say they're available to give his life on behalf of } \\
\text { others or of values; } \\
\text {-Power, with expressive } 0.4 \% \text {, preceded the money with } \\
6.4 \% \text {. }\end{array}$ \\
\hline
\end{tabular}




\section{Continued}

\begin{tabular}{|c|c|c|c|c|c|}
\hline Teixeira, C. & 2011 & $\begin{array}{l}\text { Characterize the personal } \\
\text { values of political consumers }\end{array}$ & Mixed & 458 & $\begin{array}{l}\text {-Core values described were the hedonism and } \\
\text { self-direction; } \\
\text {-College students political consumers enhance anti } \\
\text { transcendence, equality, concern and well-being of } \\
\text { others. }\end{array}$ \\
\hline $\begin{array}{l}\text { Arambewela, R. } \\
\text { \& John, H. }\end{array}$ & 2011 & $\begin{array}{l}\text { Evaluate the influence of } \\
\text { personal values in } \\
\text { improving the satisfaction of } \\
\text { students' experience }\end{array}$ & Qualitative & & $\begin{array}{l}\text {-Argue that the personal values are predictors of } \\
\text { individual behaviour and decision-making that could have } \\
\text { an impact on the college experience and satisfaction with } \\
\text { the learning environment. }\end{array}$ \\
\hline Fernandes, C. & 2012 & Validate the scale of values & Quantitative & 335 & $\begin{array}{l}\text {-The values of life are positively associated with } \\
\text { satisfaction with life, self-compassion, as well as the } \\
\text { well-being and mental health }(p<0.05) \text {. }\end{array}$ \\
\hline Pires, L. & 2012 & $\begin{array}{l}\text { Study the attitudes and } \\
\text { values of college students }\end{array}$ & Mixed & & $\begin{array}{l}\text {-Five most important qualities for the student: } \\
\text { responsibility }(89 \%) \text {, be tolerant and respect others }(88 \%) \text {, } \\
\text { good manners }(81 \%) \text {, worker }(54.6 \%) \text {, determined and } \\
\text { persevering }(49.6 \%) \text {, equality and not be selfish }(49.4 \%) \text {; } \\
\text {-The responsibility is higher than public universities, but } \\
\text { being a worker is in the private University; } \\
\text {-In males is valued imagination and among the female } \\
\text { literacy to tolerance, respect, obedience. }\end{array}$ \\
\hline $\begin{array}{l}\text { Ulucinar, U., } \\
\text { Akar, C., } \\
\text { Demir, M., \& } \\
\text { Demirhan, G. }\end{array}$ & 2012 & $\begin{array}{l}\text { Analyze the epistemological } \\
\text { belief in Usak University } \\
\text { students in function of } \\
\text { several variables }\end{array}$ & Quantitative & 321 & $\begin{array}{l}\text {-The results show that there are differences of meaning } \\
\text { between epistemological beliefs of college students and } \\
\text { their colleges, departments, family education, } \\
\text { socio-economic level of religiosity and habit of reading. }\end{array}$ \\
\hline Jarrar, A. & 2013 & $\begin{array}{l}\text { Study the educational } \\
\text { system of moral value that } \\
\text { believe the Jordanian youth } \\
\text { at private universities }\end{array}$ & Quantitative & & $\begin{array}{l}\text {-Believe that no moral crisis in society; } \\
-60.5 \% \text { point religious values; } \\
-28.7 \% \text { to } 23.6 \% \text { for the spiritual, the emotional value, } \\
14.5 \% \text { for the social value, } 7.8 \% \text { to biology; } \\
\text {-values such as caring for the body and the right to life and } \\
5.1 \% \text { for mental values; } \\
-74 \% \text { the economic situation of the family is an important } \\
\text { factor in moral education; } \\
-24.3 \% \text { of respondents believed that the most important } \\
\text { role in education is due to family, } 23 \% \text { to } 7.1 \% \text {, media } \\
\text { schools and } 2 \% \text { for College; } \\
\text {-Shows that } 57.4 \text { percent of the respondents believed that } \\
\text { the most important role in education is due to develop a } \\
\text { spirit of subordination of the moral system, and } 35.1 \% \text { of } \\
\text { the respondent believed that the development of } \\
\text { consciousness and personal morality, } 4.1 \% \text { believed that } \\
\text { the development of a spirit of brotherhood, and } 2 \% \\
\text { believed the development of the spirit of the well; } \\
\text {-To resist the temptation, } 30.4 \% 25.3 \% \text { honesty, sense of } \\
\text { guilt when the error and } 9.1 \% 3 \text { sacrifice altruism; } \\
-56.4 \% \text { of the respondents agree with the missing students } \\
\text { with the standard of honesty in negotiating. }\end{array}$ \\
\hline Parra, M. & 2014 & $\begin{array}{l}\text { Describe the values in } \\
\text { students Nursing University } \\
\text { of Santander }\end{array}$ & $\begin{array}{l}\text { Quantitative } \\
\text { correlational }\end{array}$ & & $\begin{array}{l}\text {-Female literacy present values such as spirituality } \\
(p<0.03) \text {; } \\
\text {-Students with less than } 5 \text { semesters feature greater } \\
\text { obedience to students more than } 6 \text { semesters }(p<0.02) \text {. }\end{array}$ \\
\hline $\begin{array}{l}\text { Rosa, A., Nunes, } \\
\text { J., Grohmann, } \\
\text { M., Battistella, L., } \\
\text { Silva, C., \& } \\
\text { Brusius, M. }\end{array}$ & 2014 & $\begin{array}{l}\text { Analyse the influence of } \\
\text { profile of University } \\
\text { students in relation to their } \\
\text { individual values }\end{array}$ & Quantitative & 216 & $\begin{array}{l}\text {-Value the self-respect, the relationship and the } \\
\text { realization; } \\
\text {-Women show more confidence, self-respect in relation to } \\
\text { men }(p<0.05) \text {. }\end{array}$ \\
\hline
\end{tabular}




\section{Continued}

\begin{tabular}{|c|c|c|c|c|c|}
\hline $\begin{array}{l}\text { Koroglu, O. \& } \\
\text { Gezen, T. }\end{array}$ & 2014 & $\begin{array}{l}\text { Determine the values of } \\
\text { work of students of tourism }\end{array}$ & Qualitative & 397 & $\begin{array}{l}\text {-The safety factors, success, work environment and } \\
\text { relationships with fellow are most important to the } \\
\text { students of tourism; } \\
\text {-There are significant differences by age, gender, and } \\
\text { class-based differences on some dimensions of the value of } \\
\text { the work of the students. }\end{array}$ \\
\hline $\begin{array}{l}\text { Falanga, R., } \\
\text { Caroli, M., \& } \\
\text { Sagone, E. }\end{array}$ & 2014 & $\begin{array}{l}\text { Explore ethnic stereotypes, } \\
\text { prejudice to the Africans } \\
\text { and the relationships } \\
\text { between these two } \\
\text { dimensions in Italian } \\
\text { University students }\end{array}$ & Qualitative & & $\begin{array}{l}\text {-Attach greater prestigious intellectual jobs for Italians and } \\
\text { the practical work/manuals for Africans; } \\
\text {-Students attach more intellectual prestige and } \\
\text { employability for the Italians and emphasize the practical } \\
\text { work/manuals for Africans, affecting the friendship. }\end{array}$ \\
\hline $\begin{array}{l}\text { Sagone, E. \& } \\
\text { Caroli, M. }\end{array}$ & 2014 & $\begin{array}{l}\text { Relating the self-concept, } \\
\text { future employment and } \\
\text { values in colleges of Catania, } \\
\text { Italy }\end{array}$ & Quantitative & 312 & $\begin{array}{l}\text {-Tackle that social exclusion is a multidimensional } \\
\text { concept, reflects a combination of interrelated factors with } \\
\text { the potential to prevent people from full participation in } \\
\text { society; } \\
\text {-By conducting a principal components analysis, } \\
\text { identifies ten factors, including legitimacy, legality, } \\
\text { social relationship, quality of accommodation, facilities, } \\
\text { extracurricular activities, accessibility, safety, comfort, } \\
\text { academic services and transportation were extracted. }\end{array}$ \\
\hline Silva, N. & 2015 & $\begin{array}{l}\text { Check public values, private } \\
\text { and/or linked to the glory of } \\
\text { college students }\end{array}$ & Quantitative & 170 & $\begin{array}{l}\text {-32.0\% relate to friendship, and } 35.0 \% \text { intelligence, } \\
\text { conceive of such excellence as a means of achieving } \\
\text { social status and wealth; } \\
\text {-Pointed out the friendship as the more considered by } \\
\text { their peers around } 40.0 \% \text { indicated as the reason that she } \\
\text { provides the adaptation to a new reality of family } \\
\text { members; } \\
\text {-Value harmony and downplay the public duties. }\end{array}$ \\
\hline $\begin{array}{l}\text { Pereira, A. \& } \\
\text { Cardoso, F. }\end{array}$ & 2015 & $\begin{array}{l}\text { Assess suicidal ideation in } \\
\text { College populations }\end{array}$ & Qualitative & & $\begin{array}{l}\text {-Prevalence of suicidal ideations of } 10.7 \% \text {; } \\
\text {-Refer to give little sense to life. }\end{array}$ \\
\hline Miguel, M. & 2015 & $\begin{array}{l}\text { Study the perspectives of } \\
\text { college students and } \\
\text { employers about the } \\
\text { professional insertion }\end{array}$ & Quantitative & 326 & -conformity, benevolence and security. \\
\hline
\end{tabular}

In relation to the year of publication, has identified the prevalence of studies published in 2014 and 2015 with 4 articles each year and, then, were the years of 2008, 2011, 2012 and 2016 with 3 articles each year. An article was published in the years 2009, 2010 and 2013. It was observed that the values inherent to college students present a limited number of research, although with some concern over the past fifteen years, which could be supposed to be due to the international crisis.

Methodologically it was found that most studies are quantitative. Data collection instruments, the most commonly used was the questionnaire. Similarly, we observe the use of qualitative methods in seven studies. Only two articles used a mixed methodology, qualitative and quantitative.

Through the analysis of the results of the studies selected, we categorize them according to the recommended values, particularly subtypes in values of experimentation, of accomplishment, of existence, super personal, interactional and normative values (Gouveia, 2008). 
Experimental values are associated with the values of life and are positively related to satisfaction with life and with self-compassion $(p<0.05)$ (Fernandes, 2012). The main values related to this type were hedonism, self-direction (Teixeira, 2011), emotional value (Jarrar, 2013), promoting the construction of moral personalities, with the promotion of role from experience, the discussion and the confrontation of social moral conflicts (Novak, 2008). The value of hedonism was referenced as a prized value in third world countries (Lins, 2010). In this type of value was mentioned that men appreciate the excitement, fun and pleasure of life (8.17), related to the amusement, leisure and recreational activities (Costa, 2008). Also we found that the prevalence of suicidal ideations is $10.7 \%$ as referred to give little sense to life (Pereira \& Cardoso, 2015).

There are studies that emphasize the values of accomplishment (Rosa et al., 2014) reporting the sense of accomplishment (7.95) and self-realization (7.76) (Costa, 2008), and demonstrate positive relations between values, auto concepts and future employment (Sagone \& Caroli, 2014). Mention that the safety factors, success, work environment and relations with social pairs are most important to the students of tourism. In addition, there are significant differences by age, gender, type of department and class differences, based on some dimensions of the value of work of students (Koroglu \& Gezen, 2014). Studies have reported positive correlation between the sense of accomplishment and self-respect $(\mathrm{r}=$ $0.625, p<0.01)$, between the self-respect and safety $(\mathrm{r}=0.560, p<0.01)$, between the sense of accomplishment and self-actualization $(\mathrm{r}=0.546, p<0.01)$ and between the warm relations with others and excitement $(\mathrm{r}=0.516, p<0.01)$ (Costa, 2008). We found that the female gives priority to self-actualization linked to personal realisation and professional (Costa, 2008) and both sexes appreciate the realization (11.47) (Almeida \& Tavares, 2009). Another study indicates the power with $0.4 \%$, preceded the have money with $6.4 \%$ (Cruz, 2011), having people human values as contentious, dramatic, accurate and open (Park \& Kim, 2008). Another author reveals that Italians attach greater prestigious intellectual jobs and that Africans favour more the practical work/manuals, affecting friendship (Falanga, Caroli, \& Sagone, 2014).

With regard to existence values, the values of life are positively associated with the well-being and mental health $(p<0.05)$ (Fernandes, 2012) reporting $5.1 \%$ for mental values, revealing the values with the care of the body and the right to life (Jarrar, 2013).

As regards the above personal values were reported humility (12.80) (Almeida \& Tavares, 2009), dignity (16\%) (Cruz, 2011), conformity, benevolence, security (Miguel, 2015), self-respect (Rosa et al., 2014), honesty (30.4\%), feeling of guilt (25.3\%), altruism (9.1\%) and the capacity of negotiation (56.4\%) (Jarrar, 2013). The five qualities listed as important to the student were responsibility (89\%), be tolerant and respect others $(88 \%)$, good manners $(81 \%)$, worker $(54.6 \%)$, determined and perseverance (49.6\%), equality and not be selfish (49.4\%) (Pires, 2012). The responsibility is a value reported by various authors, showing 11.65 results for this value (Almeida \& Tavares, 2009), and this is higher than in the 
public universities, but the fact of the worker is higher than private institutions (Pires, 2012). Another author mentions the responsibility, commitment, persistence and trust in themselves, hope to have a promising future, to accomplish their goals, crowned with strong feelings from their experiences, understanding the entrepreneurship as a form of social development (Carvalho, 2016). Personal values are predictors of individual behaviour and decision-making that could have an impact on the college experience and satisfaction with the learning environment (Arambewela \& John, 2011). First world countries were associated individual development values and materialism (Lins, 2010). The male values more responsibility (12.43), independence (11.49) and the imagination (Pires, 2012) and female literacy prevails the responsibility (13.03), independence (11.74) (Almeida \& Tavares 2009), tolerance, respect, obedience (Pires, 2012), security and self-respect (Rosa et al., 2014).

With regard to the interactive values, the highest are, be respected (8.24), safely (7.83) (Costa, 2008), dialogue, solidarity, equality and participation (Novak, 2008). The lower rating, but still positive, were warm relations with others (6.63), sense of belonging (6.21), excitement (5.96) (Costa, 2008). In this type of value is appreciated the concern with the environment (11.61) and with the other (11.49), loyalty to family and group (11.45) (Almeida \& Tavares, 2009), relationship (Rosa et al., 2014) and be available to give his life on behalf of others or of values (86.5\%) (Cruz, 2011). Pointed to the friendship (32.0\%) and intelligence $(35.0 \%)$ as the most value considered by their peers around $40.0 \%$ indicated as a reason the fact provide adaptation to a new reality distant of family members (Silva, 2015). Other authors elect the family as a generator for your motivation and in the construction of their ways, setting out to conquer your dreams and wishes (Carvalho, 2016), point $14.5 \%$ for the social value, $7.8 \%$ to the biological, $74 \%$ the economic situation of the family as an important factor in moral education, $24.3 \%$ believed that the most important role in education is due to family, $23 \%$ to the media (media), $7.1 \%$ to schools and $2 \%$ to the University (Jarrar, 2013). Social exclusion is reported as a multidimensional concept, reflects a combination of interrelated factors with the potential to prevent people from full participation in society. By conducting a principal components analysis, ten factors are included on legitimacy/legality, social relationship, quality of accommodation, facilities, extracurricular activities, accessibility, safety, comfort, academic services (Sedaghatnia et al., 2015). College student's political consumers enhance against transcendence, equality, concern and well-being on the other (Teixeira, 2011) and the Asian students are more individualistic, uncommunicative and interpersonal sensitivity in relation to European Americans (Park \& Kim, 2008). There's that valuing the importance of the guidance and constant support of culturally different students for social integration, academic, achievement of autonomy and interpersonal relationships. Male students value the concern with the environment (11.42) and females consider concern for others (11.84) and with the environment (11.73) (Almeida \& Tavares, 2009).

The normative value is mentioned the importance of religion $(16.6 \%$ and 
60.5\%) (Jarrar, 2013; Cruz, 2011) and spirituality $(p=0.03)(28.7 \%)$ (Jarrar, 2013; Almeida \& Tavares, 2009). The results show that there are differences of meaning between epistemological beliefs of college students and their colleges, departments, family education, socio-economic level, religiosity and reading habits (Ulucinar et al., 2012). In contrast, third world countries were related values of social justice, professional development, and religiosity (Lins, 2010). Report that there is no moral crisis in society and that the most important role in education is due to develop a spirit of subordination of the moral system (57.4\%), of conscience and morals (35.1\%), development of a spirit of brotherhood (4.1\%) and development of the spirit of the well (2\%). Students value the individual harmony and depreciate the public duties (Silva, 2015). We found that students with less than five semesters feature greater obedience to students with more than six semesters $(p<0.02)$ (Parra, 2014).

\section{Discussion}

The results described above emphasize the current need to increase the empirical evidence, as well as to make known the values associated with the students.

We found that the values of experimentation they invoke enjoy emotions, pleasure, being a personal orientation and the value of the achievement report the power, prestige and success as a result of their studies and goals for the future. This last value student highlights the realization, self-realization, self-respect and safety.

With regard to existential values, college students made reference to the values of life and the meanings attributed to this, as well as the well-being and mental health.

However, most studies in this systematic review enhance individual and interactional values. In the first report the knowledge and maturity of University students, making reference to responsibility, respect, tolerance and independence, as well as to the dignity, individual attitudes and behaviours based on personal values. Still we find other authors who report confidence and hope for a promising future. As for interactive values, college students prioritize the affection, relationships and society support in achieving their goals. In these, students report solidarity, dialogue, respect and concern/respect for others and the environment. Mention the interpersonal relationship to society and the family, as well as loyalty and well-being with these.

Nevertheless, the students mention the spiritual values/religiosity, referring to the beliefs, moral crises, development of the well inspirations and individual harmony.

\section{Conclusion}

Reflection on the ability of these same values has in the formation of a full citizen, and is ready to live in society and of great importance for the implications in the training of young students. The trajectory of this study had as initial focus the unrest we understand the design of the students, about the construction 
process of human values in everyday life of the school, analysing whether it is possible to exist this construction and development. To this end, some conclusions may serve as a starting point for new studies and personal investigations and other researchers who are interested in the subject.

Education is not the same as teaching content. At present the school has on your responsibility much more than simply administer and transmitting knowledge, having in itself the function of forming social individuals along with the family. To educate is to form the full set of attributes that generates a complete and quality education where they can't miss the construction and development of solid human moral and ethical values.

One of his contributions is the emphasis on care practice as interpersonal, based on factors that result in the satisfaction of human needs, promoting health and individual and family growth, as well as in understanding the environment as favouring personal development and integrated biophysical and human behavioral knowledge.

Finally, and still on the basis of the results obtained, we also suggest the development of more research to give a greater empirical consistency to this theme, our college students, and so contribute to the practice/teaching excellence based on evidence. In this context, the author currently is developing a survey where the primary goal is aimed at identifying the values of a representative sample of students from Madeira, Portugal.

\section{References}

Almeida, L., \& Tavares, P. (2009). Valores de Vida em Estudantes Universitários de Cursos Tecnológicos e de Humanidades. Avaliação Psicológica, 8, 156-168.

Arambewela, R., \& John, H. (2011). The Role of Personal Values in Enhancing Student Experience and Satisfaction among International Postgraduate Students: An Exploratory Study. Procedia-Social and Behavioral Sciences, 29, 1807-1815. https://doi.org/10.1016/j.sbspro.2011.11.428

Carvalho, M. (2016). O Valor do Empreendedorismo na Universidade: Perspetivas dos Alunos do Curso de Administração da Faculdade de Padrão-Goiânia/Goiás. Dissertação de Mestrado, Porto: Universidade Fernando Pessoa.

Costa, H. (2008). Uma Análise dos Valores dos Jovens Consumidores Portugueses: Aplicação da Escala List of Values (LOV). Lisboa: Faculdade de Ciências Humanas e Sociais.

Cruz, E. (2011). Valores e Ientidades dos Estudantes Universitário Angolanos. Dissertação de Mestrado, Lisboa: Instituto Universitário de Lisboa.

Falanga, R., Caroli, M., \& Sagone, E. (2014). The Relationship between Stereotypes and Prejudice toward the Africans in Italian University Students. Procedia-Social and Behavioral Sciences, 159, 759-764. https://doi.org/10.1016/j.sbspro.2014.12.444

Fernandes, C. (2012). Validação da Versão Portuguesa da Escala de Valores Numa Amostra de Estudantes Universitários. Dissertação de Mestrado, Coimbra: Universidade de Coimbra. Faculdade de Psicologia e de Ciências da Educação.

Goergen, P. (2005). Pós-Modernidade, Ética e Educação. Campinas: Autores Associados.

Gouveia, V. (2008). Teoria Funcionalista dos Valores Humanos. In M. Teixeira (Ed.), Valores Humanos e Gestão: Novas Perspectivas (pp. 47-80). São Paulo: Senac. 
Jarrar, A. (2013). Moral Values Education in Terms of Graduate University Students' Perspectives: A Jordanian Sample. International Education Studies, 6, 136-147. https://doi.org/10.5539/ies.v6n2p136

Koroglu, O., \& Gezen, T. (2014). An Investigation to Determine the Work Values of Tourism Students. Procedia-Social and Behavioral Sciences, 131, 253-257. https://doi.org/10.1016/j.sbspro.2014.04.113

Lins, S. (2010). Valores Sociais e Preconceito Racial: Como Percebo a Mim e ao Outro. Dissertação de Mestrado, Paraíba: Universidade Federal da Paraíba.

Marques, R. (2007). Cidadania na Escola. Lisboa: Livros Horizonte.

Miguel, M. (2015). Inserção Profissional e Valores no Trabalho: Perspetivas dos Estudantes Universitários e das Entidades Empregadoras em Angola. Dissertação de Mestrado, Lisboa: Instituto Superior de Economia e Gestão.

Novak, F. (2008). A Construção de Valores no Ensino Superior: Um Estudo Sobre a Formação Ética de Estudantes Universitários. Dissertação de Mestrado, São Paulo: Universidade de São Paulo, Faculdade de Educação.

Park, Y., \& Kim, B. (2008). Asian and European American Cultural Values and Communication Styles among Asian American and European American College Students. Cultural Diversity and Ethnic Minority Psychology, 14, 47-56. https://doi.org/10.1037/1099-9809.14.1.47

Parra, M. (2014). Valores en Los Estudiantes de Enfermería de la Universidad de Santander. Avances en Enfermeria, 32, 11-24. https://doi.org/10.15446/av.enferm.v32n1.45974

Pereira, A., \& Cardoso, F. (2015). Ideação Suicida na População Universitária: Uma Revisão de Literatura. Revista $E-P S i, 5,15-34$.

Pires, L. (2012). Representações Sociais dos Valores dos Estudantes Universitários Portugueses. Dissertação de Mestrado, Aveiro: Universidade de Averio.

Rosa, A., Nunes, J., Grohmamn, M., Battistella, L., Silva, C., \& Brusius, M. (2014). A Mensuração dos Valores Pessoais dos Estudantes Universitários. Estudos do ISCA, 10, $1-17$.

Sagone, E., \& Caroli, M. (2014). Professional Values and Self-Concepts in High School Students. Procedia-Social and Behavioral Sciences, 114, 216-221.

https://doi.org/10.1016/j.sbspro.2013.12.688

Saviani, D. (2002). Educação: Do Senso Comum à Consciência Filosófica (14a ed.). São Paulo: Autores Associados.

Schwartz, S. (2006). Há Aspectos Universais na Estrutura e no Conteúdo dos Valores Humanos? In M. Ros, \& V. Gouveia (Eds.), Psicologia Social dos Valores Humanos: Desenvolvimentos Teóricos, Metodológicos e Aplicados (pp. 55-85). São Paulo: Senac.

Sedaghatnia, S., Lamit, H., Abdullah, A., \& Ghahramanpouri, A. (2015). Experience of Social Inclusion among Students in University Campuses of Malaysia. Procedia-Social and Behavioral Sciences, 170, 89-98. https://doi.org/10.1016/j.sbspro.2015.01.018

Silva, F. (2006). Cultura Escolar: Quadro Conceitual e Possibilidades de Pesquisa. Educar, 28, 201-216. https://doi.org/10.1590/S0104-40602006000200013

Silva, N. (2015). Valores Priorizados por Estudantes Universitários de um Curso de Psicologia de uma Universidade Pública. Educação e Pesquisa, 41, 391-407. https://doi.org/10.1590/S1517-97022015041615

Teixeira, C. (2011). Os Valores Pessoais Associados ao Consumo Politico: Um Estudo Exploratório com Estudantes Universitários. Porto Alegre: Universidade Federal do Rio Grande do Sul. 
Ulucinar, U., Akar, C., Demir, M., \& Demirhan, G. (2012). An Investigation on Epistemological Beliefs of University Students. Procedia-Social and Behavioral Sciences, 46, 5133-5137. https://doi.org/10.1016/j.sbspro.2012.06.396

Submit or recommend next manuscript to SCIRP and we will provide best service for you:

Accepting pre-submission inquiries through Email, Facebook, LinkedIn, Twitter, etc. A wide selection of journals (inclusive of 9 subjects, more than 200 journals)

Providing 24-hour high-quality service

User-friendly online submission system

Fair and swift peer-review system

Efficient typesetting and proofreading procedure

Display of the result of downloads and visits, as well as the number of cited articles Maximum dissemination of your research work

Submit your manuscript at: http://papersubmission.scirp.org/

Or contact ce@scirp.org 